\title{
Revisiting the discovery of the $\alpha \beta$ TCR complex and its co-receptors
}

\author{
Ellis L. Reinherz * \\ Laboratory of Immunobiology, Department of Medical Oncology, Dana-Farber Cancer Institute, Boston, MA, USA \\ *Correspondence: ellis_reinherz@dfci.harvard.edu \\ Edited by: \\ Kendall A. Smith, Weill Medical College of Cornell University, USA \\ Reviewed by: \\ Salvatore Valitutti, INSERM, France \\ Nick Gascoigne, National University of Singapore, Singapore
}

Keywords: adaptive immunity, thymic development, co-receptors, TCR, CD3

This is an opinion article based on the paper "Clonotypic structures involved in antigen-specific human $\mathrm{T}$ cell function. Relationship to the T3 molecular complex", by Meuer S. C., Fitzgerald K. A., Hussey R. E., Hodgdon J. C., Schlossman S. F., and Reinherz E. L. (1).

Life and science do not necessarily follow a straightforward path. So, it is not surprising, in retrospect, that my decision around Christmas of 1977 to terminate my clinical hematology fellowship in favor of a laboratory research associate position at Dana-Farber Cancer Institute working on lymphoid malignancies would result in progress in basic immunology. Remarkably, however, the outcome of the research yielded new insights into thymic development, mature T-cell heterogeneity, and the molecular basis for cognate recognition by T lymphocytes.

At the time, my decision was motivated by a clinical observation and desire to understand its basis. Namely, if a physician treated 100 children with acute lymphoblastic leukemia (ALL) using the same multi-agent chemotherapy, 80 of them would go into remission and 20 of them would die. I asked myself if that latter outcome was $100 \%$ of $20 \%$ vs. $20 \%$ of $100 \%$. I thought that the answer might be the former but sought the opinion of a clinical mentor. He looked at me as if I had three heads and simply commenting that those who die have "poor protoplasm." This abject ignorance was so appalling and annoying to me at the same time that I quit on the spot. Since I had bluntly told him what I thought of his response, I likely would have been fired if I had not voluntarily chosen to move on down the road quite literally, as it were. While I had no explicit experimental plans, it occurred to me that antibodies raised against these tumor cells might be capable of distinguishing subpopulation heterogeneity, should it exist. After all, in 1977, people were not distinguishing red blood cells from different individuals by holding them up to the light. In the 1920s, a man named Landsteiner sorted out differences among RBCs that looked alike through development of red blood cell typing technology (2).

In any event, I moved to Dana-Farber Cancer Institute to work with Stuart Schlossman, who was Chief of the Division of Tumor Immunology, which included his own laboratory, that of Harvey Cantor, and several others. Stu enthusiastically greeted me at the time. He was appreciative of my query since he, himself, was trained as a hematologist and attempting to dissect normal lymphoid heterogeneity. His laboratory already was generating rabbit antisera against various types of hematopoietic cells. He told me that he was just starting the production of monoclonal antibodies (mAbs) using the Kohler and Milstein method (3) and that I might get involved. I retrieved human thymuses from children and neonates undergoing open heart surgery for congenital cardiac abnormalities, peripheral T-cells from normal volunteers isolated by sheep erythrocyte rosetting (a way of fractionating human T-cells), and a host of leukemic populations from my earlier patients. We used human cells to immunize mice in an effort to stimulate antibody production. The combination of the species differences as well as FACS-based screening of B-cell hybridoma supernatants in lieu of radioimunoassays employed by most other groups permitted us to quickly identify antibody targets, even when not expressed at high levels on cells or restricted to a subpopulation of those cells being interrogated. As a consequence, it was rather simple to derive mAbs against targets on subpopulations of mature and immature $\mathrm{T}$ lineage cells.

In 1979, we first identified the CD4 molecule, which we found to be expressed on two-thirds of peripheral mature $\mathrm{T}$ lymphocytes with helper activity (4-6) and then CD8 molecules expressed on the reciprocal subset of T-cells, which manifest most of the cytotoxic activity (7). In contrast, within the thymus itself, we originally described the major population of thymocytes co-expressing CD4 and CD8, which we termed double positive (DP) as precursors of mature thymocytes (8). In addition, we observed a small subset of $\mathrm{CD}^{-} \mathrm{CD}^{-}$(double negative, $\mathrm{DN}$ ) thymocytes. The vast majority of ALLs refractory to chemotherapy (those 20\% above) was derived from the DN thymocytes (8). Susceptibility of this DN thymocyte population to activating mutations in NOTCH and aberrations of competitive niches created during early development are currently evolving as explanations of thymocyte susceptibility [(9) and references therein]. The fact is even without detailed molecular understanding of these immature ALLs and more mature T lineage malignancies like acute lymphoblastic lymphoma and Sezary syndrome, it was obvious that such tumors represented frozen states of normal $\mathrm{T}$ lineage development. The notion that thymocyte development progressed from DN to DP to 
SP $\left(\mathrm{CD} 4^{+} \mathrm{CD} 8^{-}\right.$or $\left.\mathrm{CD}^{-} \mathrm{CD} 8^{+}\right)$derived from our studies. Acceptance of this idea had to wait more than 4 years for the mouse immunologists to create the anti-murine CD4 mAb equivalent, L3T4 (10). The use of these mAbs revolutionized mature T-cell subset characterization in human beings offering CD4/CD8 clinical ratios, absolute CD4 counts, and the like. Comparative analysis done with Lorenzo Loretta and Max Cooper using other then currently accepted methods revealed that the new approach to define $\mathrm{T}$ lymphoid heterogeneity with $\mathrm{mAbs}$ was superlative to those existing technologies (11).

In 1980, we first observed that the antiCD3 mAb could block antigen-specific human T-cell proliferation to both soluble antigens and alloantigens, as well as inhibit generation of cytotoxic T-cells (12). Of note, $\mathrm{CD} 3$ was expressed at latter stages of thymic development but maintained on all mature peripheral T-cells. Moreover, antigen recognition by human $\mathrm{T}$ lymphocytes was linked to surface expression of the CD3 molecular complex. When human Tcell clones were incubated with anti-CD3 $\mathrm{mAb}$ at $37^{\circ} \mathrm{C}$, there was a rapid and selective loss of CD3 expression and concomitant antigen unresponsiveness (13). The latter was not a generalized cellular inhibition since IL-2 responsiveness remained intact. Removal of anti-CD3 from cell culture $\mathrm{mAb}$ was followed by restoration of T-cell surface CD3 expression and, in parallel, return of antigen responsiveness. These data set the stage for Ortho/Johnson \& Johnson Pharmaceuticals to develop OKT3 as a human immunosuppressive therapeutic that was tested in treatment of allograft transplant rejection and became the very first FDA approved mAb in $1985(14,15)$.

Because research productivity went well, I was promoted to Assistant Professor in the Medicine Department at Harvard Medical School in 1980. Baruj Benacerraf had both taken over the helm of DFCI that year as its president and won the Nobel Prize in Physiology or Medicine in 1980 with Jean Dausset and George Snell for "their discoveries concerning genetically determined structures on the cell surface that regulate immunological reaction," i.e., MHC. As a newly minted faculty member, Baruj summoned me to his office so that I could describe to him the plans for my fledgling research operation. I told Dr. Benacerraf that all of my efforts were going to focus on defining T-cell antigen recognition, including identification of the T-cell receptor. He told me that this goal was ambitious, bold but probably ill advised. There were too many established laboratories working on this central immunological problem. "What makes you think it's likely that you will succeed over them?" he queried. I responded: "I'm looking for the receptor on the surface of a $\mathrm{T}$ cell, not in culture supernatants as the others are doing." $\mathrm{He}$ shrugged, wished me luck, and so the next phase began. In the several years that followed when success was achieved, it should be noted that Baruj was laudatory and glad I followed my scientific conviction.

In 1982, by exploiting T-cell cloning techniques, first described by Smith and colleagues (16), alloreactive CTL could be derived from both human CD4 and CD8 subsets. Strikingly, CD4 T-cells recognized MHC class II products, whereas CD8 Tcells recognized MHC class I products. These cells could be blocked by appropriate anti-MHC I/II or anti-CD4 or anti-CD8 antibodies (17-22). Given that anti-CD3, anti-CD4, and anti-CD8 mAbs all blocked CTL activity, we wondered whether the surface molecules identified by these mAbs detected recognition elements or, alternatively, components of the lytic machinery. Lectin approximation studies excluded the lytic machinery option since even in the presence of the blocking antibodies, lectin restored CTL function, although pointedly with loss of target specificity.

The fact that biochemical analysis [see, for example, in Ref. $(23,24)]$ failed to identify differences in peptide maps or electrophoretic mobility of these molecules on human T-cell clones of differing specificities argued that they were invariant structures incapable of conferring antigen and MHC specificities per se. Because each cloned T lymphocyte recognizes antigen in a precise fashion, one could not account for its unique specificity on the basis of monomorphic portions of $\mathrm{CD} 3$, CD4, or CD8 (1). I reasoned that there had to exist discriminative surface structures on individual clones, which we refer to as clonotypes or idiotypes. mAbs to such idiotypic structures $(\mathrm{T}$ idiotypic $=\mathrm{Ti})$ were produced next by immunizing mice with CTL clones, screening the resulting antibodies on the immunizing CTL and then selecting those which lacked reactivity with additional clones of different antigen specificities from the same donor $(1,25,26)$. Such antibodies were unique in that they inhibited cell-mediated killing and antigen-specific proliferation of the individual immunizing clone without affecting the function of other autologous clones. Moreover, like anti-CD3 mAbs, the anti-clonotypic antibodies enhanced IL-2 responsiveness and induced modulation of the Ti structure with CD3. Data showed that the Ti clonotype was closely associated with $\mathrm{CD} 3$ in the membrane of human T-cells. Immunoprecipitation and competitive binding analysis revealed that the anticlonotypes defined a disulfide-linked heterodimer with $\alpha$ and $\beta$ subunits of approximately 49 and $43 \mathrm{kD}$, respectively. The heterodimeric clonotype was not physically associated with CD4 or CD8 but was in non-covalent association with the invariant $\mathrm{CD} 3$ molecules as a complex first evidenced by our analyses $(1,23,25,26)$.

From the above data collectively, I proposed with my colleagues a working model of T-cell cognate recognition (27) in which the antigen binding structure comprised a clonally unique $\alpha \beta$ heterodimeric Ti moiety in complex with $\mathrm{CD} 3$. The associative recognition element is either CD4 or CD8 depending on the subset derivation of the individual $\mathrm{T}$ lymphocyte. In this model, CD4 and CD8 accessory ("co-receptor") glycoproteins bind to constant regions of class II or class I MHC, respectively, which are separate from the CD3-linked clonotype. The TCR complex, on the other hand, was defined as a CD3-associated Ti $\alpha \beta$ heterodimer working in concert with $\mathrm{CD} 4$ and CD8 to mediate MHC-restricted antigen recognition. This view implied that there was a bidentite interaction of the TCR complex and co-receptor with the same peptide/MHC. This proposal has been codified in structural studies over the last 30 years [for review, see Ref. (28)]. Confidence that Ti was the $\alpha \beta$ TCR heterodimer encoding both peptide and MHC specificities came from (1) the unique ability of anti-clonotypic mAbs coupled to Sepharose beads to trigger T-cell clones, replacing requirements for cognate antigen plus MHC (29); (2) biochemical evidence for peptide variability within $\alpha$ and $\beta$ subunits of $\mathrm{Ti}(30,31)$, implying existence of constant and variable regions as found in 
Ig heavy and light chains; (3) $\alpha \beta$ purification and amino acid sequencing showing Ig homologies for each subunit $(32,33)$; (4) the putative TCR triggering resulted in T-cell proliferation via an IL-2-dependent mechanism not observed by crosslinking other T-cell structures (34); and (5) direct evidence for the existence of nominal antigen binding sites on $\mathrm{Ti} \alpha \beta$ heterodimers of MHC-restricted T-cell clones specific for fluorescein-5-isothiocyanate (35).

The work carried out over a period of these several years was extraordinarily exciting, converting concepts into explicit molecular identities, beginning to explain the complexities of T-cell recognition, providing reagents for clinical efforts and fodder for considerable future structural and molecular studies. These TCR efforts required a spirited collection of colleagues including Stefan Meuer who developed Tcell clones and performed many functional studies with Rebecca Hussey who made the various mAbs used in the majority of these studies, and Oreste Acuto who led the biochemical charge on the TCR complex and TCR $\alpha \beta$ heterodimer purification and amino acid sequencing with Marina Fabbi. Bob Siliciano then showed that the TCR $\alpha \beta$ heterodimer actually bound ligand.

Our efforts on TCR biology and its identification were complemented very soon by studies in the mouse by Pippa Marrack and John Kappler using T-cell hybridomas. More explicitly, we published in JEM in February 1983 on the first anti-clonotypic $\mathrm{mAb}(1)$, while they published in the same journal in April 1983 (36). Comparisons of TCR $\alpha \beta$ heterodimer clonotypes were published by us in Nature in June 1983 and in PNAS in July $1983(23,25)$ whereas their comparison appeared in Cell in October 1983 (37). We published on the ability of ant-clonotypic mAbs to replace the requirement of peptide and $\mathrm{MHC}$ in T-cell activation in September 1983, whereas our competitors showed that anti-clonotypic antibody binding to T-cell hybridomas predicted antigen and MHC specificity in November 1983 (38). Furthermore, their biochemical data matched well with that of the human being and an independently identified disulfide-linked T-cell tumorspecific antigen identified with a mAb produced by Allison et al. (39). The human being was a particularly informative and tractable species choice since we had created reagents that defined the TCR $\alpha \beta$ heterodimer, CD3 components, and CD4 and CD8 co-receptors. The majority of reagents defining these receptors was lacking in the mouse at the time. Biochemical detail by Terhorst and Klausner further refined the nature of the CD3 components of the TCR complex $(40,41)$. The objective impact of the three Reinherz, Marrack, and Allison group efforts from the 1980 to 2000 time period is evident from ISI citations (20,000 vs. 8,000 vs. 900 , respectively). In turn, molecular cloning of the TCR subunits using a subtractive hybridization method began (42-45). These studies identified TCR $\beta$ as shown by our subsequent $\mathrm{N}$-terminal amino acid sequencing analysis (32). More than 30 years later, however, we are still in the process of detailing structure and function of the TCR complex and its co-receptors. The trove of information herein will lead to important therapeutic inventions for treatment of autoimmune and immunodeficiency diseases to be fully realized in the coming years.

\section{REFERENCES}

1. Meuer SC, Fitzgerald KA, Hussey RE, Hodgdon JC, Schlossman SF, Reinherz EL. Clonotypic structures involved in antigen-specific human $\mathrm{T}$ cell function. Relationship to the T3 molecular complex. J Exp Med (1983) 157:705-19. doi:10.1084/jem.157. 2.705

2. Gröger H. Karl Landsteiner and medical science in Vienna around 1900. The significance of laboratory medicine for clinical medicine. Vox Sang (2000) 78(Suppl 2):3-6.

3. Köhler G, Milstein C. Continuous cultures of fused cells secreting antibody of predefined specificity. Nature (1975) 256:495-7. doi:10.1038/ 256495a0

4. Reinherz EL, Kung P, Goldstein G, Schlossman SF. Separation of functional subsets of human $\mathrm{T}$ cells by a monoclonal antibody. Proc Natl Acad Sci U S A (1979) 76:4061-5. doi:10.1073/pnas.76.8.4061

5. Reinherz EL, Kung PC, Breard J, Goldstein G, Schlossman SF. T cell requirements for generation of helper factor in man: analysis of the subsets involved. J Immunol (1980) 124:1883-7.

6. Reinherz EL, Morimoto C, Penta AC, Schlossman SF. Regulation of B cell immunoglobulin secretion by functional subsets of $\mathrm{T}$ lymphocytes in man. Eur J Immunol (1980) 10:570-2. doi:10.1002/eji. 1830100715

7. Reinherz EL, Kung PC, Goldstein G, Schlossman SF. A monoclonal antibody reactive with the human cytotoxic/suppressor $\mathrm{T}$ cell subset previously defined by a heteroantiserum termed TH2. J Immunol (1980) 124:1301-7.

8. Reinherz EL, Kung PC, Goldstein G, Levey RH, Schlossman SF. Discrete stages of human intrathymic differentiation: analysis of normal thymocytes and leukemic lymphoblasts of T lineage. Proc Natl Acad Sci U S A (1980) 77:1588-92. doi:10.1073/pnas.77.3.1588

9. Martins VC, Busch K, Juraeva D, Blum C, Ludwig C, Rasche V, Lasitschka F, Mastitsky SE, Brors B, Hielscher T, Fehling HJ, Rodewald HR. Cell competition is a tumour suppressor mechanism in the thymus. Nature (2014) 509:465-70. doi:10.1038/ nature 13317

10. Dialynas DP, Quan ZS, Wall KA, Pierres A, Quintáns J, Loken MR, Pierres M, Fitch FW. Characterization of the murine $T$ cell surface molecule, designated L3T4, identified by monoclonal antibody GK1.5: similarity of L3T4 to the human Leu-3/T4 molecule. J Immunol (1983) 131:2445-51.

11. Reinherz EL, Moretta L, Roper M, Breard J, Mingar IMC, Cooper MD, Schlossman SF. Human T lymphocyte subpopulations defined by Fc receptors and monoclonal antibodies: a comparison. $J$ Exp Med (1980) 151:969-74. doi:10.1084/jem.151. 4.969

12. Reinherz EL, Hussey RE, Schlossman SF. A monoclonal antibody blocking human $\mathrm{T}$ cell function. Eur J Immunol (1980) 10:758-62. doi:10.1002/eji. 1830101006

13. Reinherz EL, Meuer S, Fitzgerald KA, Hussey RE, Levine H, Schlossman SF. Antigen recognition by human $\mathrm{T}$ lymphocytes is linked to surface expression of the T3 molecular complex. Cell (1982) 30:735-43. doi:10.1016/0092-8674(82) 90278- 1

14. Cosimi AB, Colvin RB, Burton RC, Rubin RH, Goldstein G, Kung PC, Hansen WP, Delmonico FL, Russell PS. Use of monoclonal antibodies to T-cell subsets for immunologic monitoring and treatment in recipients of renal allografts. $N$ Engl J Med (1981) 305:308-14. doi:10.1056/ NEJM198108063050603

15. Smith SL. Ten years of Orthoclone OKT3 (muromonab-CD3): a review. J Transpl Coord (1996) 6:109-19.

16. Baker PE, Gillis S, Smith KA. Monoclonal cytolytic T-cell lines. J Exp Med (1979) 149:273-8. doi:10. 1084/jem.149.1.273

17. Ball EJ, Stastny P. Cell-mediated cytotoxicity against HLA-D-region products expressed in monocytes and B lymphocytes. IV. Characterization of effector cells using monoclonal antibodies against human T-cell subsets. Immunogenetics (1982) 16:157-69. doi:10.1007/BF00364402

18. Biddison WE, Rao PE, Talle MA, Goldstein G, Shaw S. Possible involvement of the OKT4 molecule in T cell recognition of class II HLA antigens. Evidence from studies of cytotoxic T lymphocytes specific for SB antigens. J Exp Med (1982) 156:1065-76. doi:10.1084/jem.156.4.1065

19. Krensky AM, Reiss CS, Mier JW, Strominger JL, Burakoff SJ. Long-term human cytolytic T-cell lines allospecific for HLA-DR6 antigen are OKT4+. Proc Natl Acad Sci U S A (1982) 79:2365-9. doi:10. 1073/pnas.79.7.2365

20. Meuer SC, Hussey RE, Hodgdon JC, Hercend T, Schlossman SF, Reinherz EL. Surface structures involved in target recognition by human cytotoxic T lymphocytes. Science (1982) 218:471-3. doi:10.1126/science.6981845

21. Meuer SC, Schlossman SF, Reinherz EL. Clonal analysis of human cytotoxic T lymphocytes: T4+ 
and T8+ effector T cells recognize products of different major histocompatibility complex regions. Proc Natl Acad Sci U S A (1982) 79:4395-9. doi:10. 1073/pnas.79.14.4395

22. Meuer SC, Hodgdon JC, Cooper DA, Hussey RE, Fitzgerald KA, Schlossman SF, Reinherz EL. Human cytotoxic $\mathrm{T}$ cell clones directed at autologous virus-transformed targets: further evidence for linkage of genetic restriction to $\mathrm{T} 4$ and $\mathrm{T} 8$ surface glycoproteins. J Immunol (1983) 131: $186-90$.

23. Reinherz EL, Meuer SC, Fitzgerald KA, Hussey RE, Hodgdon JC, Acuto O, Schlossman SF. Comparison of T3-associated 49/43KD cell surface molecules on individual human $\mathrm{T}$ cell clones: evidence for peptide variability in $\mathrm{T}$ cell receptor structure. Proc Natl Acad Sci U S A (1983) 80:4104-8. doi:10.1073/pnas.80.13.4104

24. Sayre PH, Reinherz EL. Structural invariance of T4 molecules from $\mathrm{T}$ cell clones of different antigen and MHC specificities. Eur J Immunol (1985) 15:291-5. doi:10.1002/eji.1830150315

25. Meuer SC, Acuto O, Hussey RE, Hodgdon JC, Fitzgerald KA, Schlossman SF, Reinherz EL. Evidence for the T3-associated $90 \mathrm{~K}$ heterodimer as the T-cell antigen receptor. Nature (1983) 303:808-10. doi:10.1038/303808a0

26. Meuer SC, Cooper DA, Hodgdon JC, Hussey RE, Fitzgerald KA, Schlossman SF, Reinherz EL. Identification of the antigen/MHC receptor on human inducer T lymphocytes. Science (1983) 222:1239-42. doi:10.1126/science.6606228

27. Reinherz EL, Meuer SC, Schlossman SF. The delineation of antigen receptors on human T lymphocytes. Immunol Today (1983) 4:5-8. doi:10.1016/ 0167-5699(83)90094-4

28. Wang JH, Reinherz EL. The structural basis of $\alpha \beta$ T lineage immune recognition: TCR docking topologies, mechanotransduction and co-receptor function. Immunol Rev (2012) 250:102-19. doi:10. 1111/j.1600-065X.2012.01161.x

29. Meuer SC, Hodgdon JC, Hussey RE, Protentis JP, Schlossman SF, Reinherz EL. Antigen-like effects of monoclonal antibodies directed at receptors on human T cell clones. J Exp Med (1983) 158:988-93. doi:10.1084/jem.158.3.988

30. Acuto O, Hussey RE, Fitzgerald KA, Protentis JP, Meuer SC, Schlossman SF, Schlossman SF, Reinherz EL. The human $T$ cell receptor: appearance in ontogeny and biochemical relationship of alpha and beta subunits on IL2 dependent clones and $\mathrm{T}$ cell tumors. Cell (1983) 34:717-26. doi:10.1016/0092-8674(83) 90528-7

31. Acuto O, Meuer SC, Hodgdon JC, Schlossman SF, Reinherz EL. Peptide variability exists within alpha and beta subunits of the $\mathrm{T}$ cell receptor for antigen. J Exp Med (1983) 158:1368-73. doi:10.1084/ jem.158.4.1368

32. Acuto O, Fabbi M, Smart J, Poole CB, Protentis J, Royer HD, Schlossman SF, Reinherz EL. Purification and NH2-terminal amino acid sequencing of the beta subunit of a human T-cell antigen receptor. Proc Natl Acad Sci U S A (1984) 81:3851-5. doi:10.1073/pnas.81.12.3851

33. Fabbi M, Acuto O, Smart JE, Reinherz EL. Homology of $\mathrm{Ti} \alpha$ subunit of a $\mathrm{T}$ cell antigen/MHC receptor with immunoglobulin. Nature (1984) 312:269-71. doi:10.1038/312269a0

34. Meuer SC, Hussey RE, Cantrell DA, Hodgdon JC, Schlossman SF, Smith KA, Reinherz EL. Triggering of the T3-Ti antigen receptor complex results in clonal $\mathrm{T}$ cell proliferation via an interleukin-2 dependent autocrine pathway. Proc Natl Acad Sci U S A (1984) 81:1509-13. doi:10.1073/pnas.81.5. 1509

35. Siliciano RF, Hemesath TJ, Pratt JC, Dintzis RZ, Dintzis HM, Acuto O, Shin HS, Reinherz EL. Direct evidence for the existence of nominal antigen binding sites on $\mathrm{T}$ cell surface $\mathrm{Ti} \alpha-\beta$ heterodimers of MHC-restricted T cell clones. Cell (1986) 47:161-71. doi:10.1016/0092-8674(86)90439-3

36. Haskins K, Kubo R, White J, Pigeon M, Kappler J, Marrack P. The major histocompatibility complexrestricted antigen receptor on $\mathrm{T}$ cells. I. Isolation with a monoclonal antibody. J Exp Med (1983) 157:1149-69. doi:10.1084/jem.157.4.1149

37. Kappler J, Kubo R, Haskins K, White J, Marrack $P$. The mouse $\mathrm{T}$ cell receptor: comparison of MHC-restricted receptors on two T cell hybridomas. Cell (1983) 34:727-37. doi:10.1016/00928674(83)90529-9

38. Marrack P, Shimonkevitz R, Hannum C, Haskins $\mathrm{K}$, Kappler J. The major histocompatibility complex-restricted antigen receptor on T cells. IV. An antiidiotypic antibody predicts both antigen and I-specificity. J Exp Med (1983) 158:1635-46. doi:10.1084/jem.158.5.1635

39. Allison JP, Mcintyre BW, Bloch D. Tumorspecific antigen of murine T-lymphoma defined with monoclonal antibody. J Immunol (1982) 129:2293-300.

40. Terhorst C, Van Den Elsen P. The T cell receptor/T3 complex. Year Immunol (1985) 1985:62-73.

41. Manolios N, Letourneur F, Bonifacino JS, Klausner RD. Pairwise, cooperative and inhibitory interactions describe the assembly and probable structure of the T-cell antigen receptor. $E M B O J$ (1991) 10:1643-51.

42. Chien YH, Gascoigne NR, Kavaler J, Lee NE, Davis MM. Somatic recombination in a murine T-cell receptor gene. Nature (1984) 309:322-6. doi:10. 1038/309322a0

43. Hedrick SM, Cohen DI, Nielsen EA, Davis MM. Isolation of cDNA clones encoding T cell-specific membrane-associated proteins. Nature (1984) 308:149-53. doi:10.1038/308149a0

44. Hedrick SM, Nielsen EA, Kavaler J, Cohen DI, Davis MM. Sequence relationships between putative T-cell receptor polypeptides and immunoglobulins. Nature (1984) 308:153-8. doi:10.1038/308153a0

45. Yanagi Y, Yoshikai Y, Leggett K, Clark SP, Aleksander I, Mak TW. A human T cell-specific cDNA clone encodes a protein having extensive homology to immunoglobulin chains. Nature (1984) 308:145-9. doi:10.1038/308145a0

Conflict of Interest Statement: The author declares that the research was conducted in the absence of any commercial or financial relationships that could be construed as a potential conflict of interest.

Received: 29 September 2014; accepted: 31 October 2014; published online: 21 November 2014.

Citation: Reinherz EL (2014) Revisiting the discovery of the $\alpha \beta$ TCR complex and its co-receptors. Front. Immunol. 5:583. doi: 10.3389/fimmu.2014.00583

This article was submitted to T Cell Biology, a section of the journal Frontiers in Immunology.

Copyright $\odot 2014$ Reinherz. This is an open-access article distributed under the terms of the Creative Commons Attribution License (CC BY). The use, distribution or reproduction in other forums is permitted, provided the original author(s) or licensor are credited and that the original publication in this journal is cited, in accordance with accepted academic practice. No use, distribution or reproduction is permitted which does not comply with these terms. 